\title{
Adaptive Calcified Matrix Response of Dental Pulp to Bacterial Invasion Is Associated with Establishment of a Network of Glial Fibrillary Acidic Protein $^{+} /$Glutamine Synthetase $^{+}$Cells
}

\author{
Ramin M. Farahani, ${ }^{+}$Ky-Anh Nguyen, ${ }^{* \dagger}$ \\ Mary Simonian, ${ }^{*}$ and Neil Hunter ${ }^{*}$ \\ From the Institute of Dental Research," Westmead Millennium \\ Institute and Westmead Centre for Oral Health, Westmead; and \\ the Faculty of Dentistry, ${ }^{\dagger}$ University of Sydney, Sydney, New South \\ Wales, Australia
}

We report evidence for anatomical and functional changes of dental pulp in response to bacterial invasion through dentin that parallel responses to noxious stimuli reported in neural crest-derived sensory tissues. Sections of resin-embedded carious adult molar teeth were prepared for immunohistochemistry, in situ hybridization, ultrastructural analysis, and microdissection to extract mRNA for quantitative analyses. In odontoblasts adjacent to the leading edge of bacterial invasion in carious teeth, expression levels of the gene encoding dentin sialo-protein were 16fold greater than in odontoblasts of healthy teeth, reducing progressively with distance from this site of the carious lesion. In contrast, gene expression for dentin matrix protein-1 by odontoblasts was completely suppressed in carious teeth relative to healthy teeth. These changes in gene expression were related to a gradient of deposited reactionary dentin that displayed a highly modified structure. In carious teeth, interodontoblastic dentin sialo-protein ${ }^{-}$cells expressing glutamine synthetase (GS) showed up-regulation of glial fibrillary acidic protein (GFAP). These cells extended processes that associated with odontoblasts. Furthermore, connexin 43 established a linkage between adjacent GFAP $^{+} / \mathrm{GS}^{+}$cells in carious teeth only. These findings indicate an adaptive pulpal response to encroaching caries that includes the deposition of modified, calcified, dentin matrix associated with networks of $\mathrm{GFAP}^{+} / \mathrm{GS}^{+}$interodontoblastic cells. A regulatory role for the networks of $\mathrm{GFAP}^{+}$/ $\mathrm{GS}^{+}$cells is proposed, mediated by the secretion of glutamate to modulate odontoblastic response. (Am J Pathol 2010, 177:1901-1914; DOI: 10.2353/ajpath.2010.100073)

Dentin is a unique calcified tissue matrix formed by odontoblasts that surround the dental pulp. In the mature tooth odontoblasts line the pulp-dentin interface and extend long cellular processes through dentinal tubules toward the dentin-enamel junction. With the primary function as dentin-forming cells, ${ }^{1}$ odontoblasts also exhibit features of innate immune cells including the expression of Tolllike pattern recognition receptors. ${ }^{2}$ Accordingly, odontoblasts recognize and react to products of Gram-positive and Gram-negative bacteria by selective engagement of different Toll-like receptors. ${ }^{3}$ Dental caries can progress to a polymicrobial invasion of dentin where from 7 to 31 bacterial taxa can be detected within a lesion. ${ }^{4}$ Bacterial invasion is associated with degradation of the dentinal matrix and stimulation of odontoblasts. Following bacterial stimulation, odontoblasts undergo major functional adaptations ${ }^{5,6}$ including deposition of intratubular dentin and accelerated dentinal matrix deposition referred to as reactionary dentin. ${ }^{7}$ Despite extensive research, the response of odontoblasts to this microbial ingress remains poorly characterized. ${ }^{8}$

Exposure of differentiated odontoblasts in primary cultures to bacterial products reduces dentin forming capacity. ${ }^{9}$ This contrasts with the observed deposition of reactionary dentin with implications for external regulation of odontoblast function. Transcriptome profiles of primary odontoblast cultures and established lines of odontoblast-like cells exhibit high similarity with the major difference involving expression of regulatory neuropep-

Supported by National Institute of Dental and Craniofacial Research grant R01 DE015272-07, Australian National Health and Medical Research Council grant 512524.3 and an Australian Dental Research Foundation grant.

Accepted for publication June 2, 2010

Address reprint requests to Ramin M. Farahani, D.D.S., Institute of Dental Research, Westmead Centre for Oral Health, Westmead Hospital, Westmead, New South Wales 2145, Australia. E-mail: rmos4386@usyd.edu.au. 
tides ${ }^{10}$ in primary odontoblast cultures with potential involvement in mediation of responses to bacterial challenge. The cross-talk through neurotransmitters could occur between pulpal nerve and odontoblasts or interodontoblastic cells and odontoblasts. Sensory denervation of dental pulp does not alter dentin-forming and immunological properties of odontoblasts, ${ }^{11,12}$ indicating a role for interodontoblastic cells. These cells form gap junction connections with adjacent odontoblasts. ${ }^{13} \mathrm{Al}-$ though the function of these cells is not clearly understood, anatomical proximity and functional coupling through gap junctions implies a regulatory role. ${ }^{14}$ Interodontoblastic cells could be involved in the response of odontoblasts to bacterial challenge, and they may be necessary for an integrated response to bacterial invasion.

The dspp gene encodes two dentin extracellular matrix proteins, dentin sialoprotein (DSP) and dentin phosphoprotein (DPP), implicated in the formation of apatite crystals in the process of dentin mineralization. ${ }^{15}$ Products of the dspp gene are critical for efficient mineralization during dentinogenesis. ${ }^{16}$ The $d m p-1$ gene encodes dentin matrix protein-1 (DMP-1) important in formation of the dentin tubular system and in mineralization. ${ }^{17,18}$ Both genes, being active in functional odontoblasts, are important markers of odontoblastic activity. Transforming growth factor- $\beta 1$ (TGF- $\beta 1$ ) is an important regulator of extracellular matrix synthesis and has been assigned an essential role in reactionary dentinogenesis. ${ }^{19}$ The interplay between these four products is central to the structural response of dental pulp to bacterial insult.

In this paper, we report a high-resolution, quantitative approach to characterize the response of dental pulp to microbial invasion. An unanticipated finding was that altered regulation of critical calcified matrix components in caries was associated with establishment of networks of cells expressing the glial markers glial fibrillary acidic protein (GFAP) and glutamine synthetase (GS). ${ }^{20,21}$ Cells comprising these networks closely associated with odontoblasts, indicating they could play a regulatory role.

\section{Materials and Methods}

\section{Materials and Reagents}

All chemicals were purchased from Sigma-Aldrich (St. Louis, MO) unless stated otherwise. The water used throughout the study was treated with diethyl polycarbonate (DEPC) to inhibit contaminating ribonucleases as described elsewhere. ${ }^{22}$

\section{Tissues}

Healthy noncarious and carious permanent teeth were obtained from male and female patients aged 26 to 42 years attending the dental clinics at the Westmead Centre for Oral Health, Westmead Hospital. The patients were otherwise healthy and did not report a history of diseases known to affect calcified tissues, the vasculature or the immune response. Molar teeth with caries originating as occlusal lesions with extensions ranging from one- to two-thirds of the dentin, were selected. The teeth were extracted for periodontal or orthodontic reasons. Healthy teeth were anatomically sound without any signs of attrition, abrasion, or erosion leading to dentinal exposure or any associated pathologies affecting the pulp-dentin complex. The ethics committee of Sydney West Area Health Service approved the study, and the guidelines of the National Health and Medical Research Council of Australia were observed. All patients received written information on the research and signed a consent form. Eight healthy and 12 diseased teeth met the inclusion criteria. These teeth were randomly allocated to light and electron microscopic studies.

\section{Processing of Specimens}

Pulp tissue was retrieved as previously described, ${ }^{23}$ with some modifications. Briefly, immediately after extraction a circumferential, longitudinal groove, was prepared on the extracted tooth using a diamond disk (Thin-Flex; Abrasive Technology, Lewis Center, $\mathrm{OH}$ ) with ample water cooling and without penetration into the dental pulp. Subsequently, the tooth was split into halves by mechanical leverage. The split tooth half with attached pulp was fixed in $2 \%$ paraformaldehyde $/ 5 \%$ sucrose in $0.02 \mathrm{M}$ phosphate buffer, pH 7.4 (680 mOsm), for 4 hours at $4^{\circ} \mathrm{C} .{ }^{24}$ Then, photographs of fixed split teeth were taken under a dissecting stereomicroscope (Leica MZ8; Leica Microsystems, Wetzlar, Germany). The fixed teeth were demineralized in Morse's solution (22.5\% formic acid and $10 \%$ sodium citrate $)^{25}$ for 3 days at $4^{\circ} \mathrm{C}$, followed by dehydration through gradual solvent exchange from pure DEPC-treated water to $100 \%$ ethanol over 45 minutes at $4^{\circ} \mathrm{C} .^{26}$

A commercial glycol methacrylate embedding kit (ImmunoBed; Polysciences, Warminster, PA) was used for embedding according to the manufacturer's protocol. Tissue blocks were stored tightly sealed at $4^{\circ} \mathrm{C}$ until the time of microtomy. Serial sections of $1-\mu \mathrm{m}$ thickness were cut on a Reichert ultracut microtome (Leica Microsystems). The sections were floated on a prewarmed DEPCtreated water bath $\left(37^{\circ} \mathrm{C}\right)$, collected using RNase-freecoated glass slides (SuperFrost Plus; Menzel-Gläser, Braunschweig, Germany), and allowed to air-dry at room temperature for 4 hours. Slides were stored at $-20^{\circ} \mathrm{C}$ until subsequent use.

\section{Localization of Bacterial Consortia}

Acridine orange was used for general tracing of the bacterial consortia within dentinal tubules. The sections were permeabilized using 1\% Triton X-100 for 2 minutes. Thereafter, Acridine orange $(0.01 \%)$ in $20 \mathrm{mmol} / \mathrm{L}$ Tris/ EDTA buffer, pH 8.0, was applied for 10 minutes, washed thoroughly with DEPC-treated water, and mounted with Aqua-Mount (Lerner Laboratories, Pittsburgh, PA). 
Table 1. Oligoprobe Sequences for ISH

\begin{tabular}{clll}
\hline Gene & Polarity & \multicolumn{1}{c}{ Sequence } & $T_{\mathrm{m}}$ \\
\hline \multirow{2}{*}{-Actin } & Antisense & $5^{\prime}$-ATCCATGGTGAGCTGGCGGC-3' & 63 \\
& Sense & $5^{\prime}$-GCCGCCAGCTCACCATGGAT-3' & 63 \\
DSPP & Antisense & $5^{\prime}$-CCCTTGATTCTATTCCTTATCTTGGCTCTTCCC-3' & 62.2 \\
& Sense & $5^{\prime}$-GGGAAGAGCAAGATAAGGAATAGAAATCAAGG-3' & 62.2 \\
DMP-1 & Antisense & $5^{\prime}$-GTCACTGGGGTCTTCATTTGCCTGTTCCTCTGA-3' & 62.2 \\
& Sense & $5^{\prime}$-GGGAAGAGCCAAGATAAGGAATAGAAATCAAGGG-3' & 62.2 \\
\hline
\end{tabular}

$T_{m}$, melting temperature.

\section{Analysis of Calcified Matrix Structure}

The hard tissue response pattern to bacterial insult was investigated using Toluidine blue-stained sections. Stained sections were analyzed using ImageJ software (version 1.410; National Institutes of Health, Bethesda, MD). Density of dentinal tubules and anisotropy of tubular structure was determined to evaluate the capacity of newly formed calcified tissue matrix to limit bacterial invasion toward the pulp. Mean density of dentinal tubules was measured in three random regions of interest (ROI) in physiological and reactionary dentin and a mean ratio calculated. The method of randomization involved random positioning through de-focusing-focusing of the microscope. For calculating the degree of structural anisotropy of tubular dentin in $\mathrm{ROI}$, the degree of anisotropy was calculated based on the following formula: degree of anisotropy $=90 /$ dispersion index, where the dispersion index is the maximum spreading angle of the longitudinal dentinal tubules in each $\mathrm{ROI}$ as originally developed for the analysis of bone. ${ }^{27}$ Dispersion index was determined after noise reduction based on ImageJ protocol.

\section{Expression Profile of Calcified Matrix-Related Genes}

In situ hybridization (ISH) was used to identify regions with active formation of reactionary dentin. Synthetic antisense oligonucleotide probes (Invitrogen, Mulgrave, Victoria, Australia), complementary to mRNA sequence of $d s p p$ and $d m p-1$, were designed to span exon-exon junctions to avoid false-positive results from crosshybridization with genomic DNA. The sequences and corresponding melting temperatures for oligoprobes are provided in Table 1. Sense probes were designed as complementary to anti-sense probes. Antisense and sense probes were labeled with Alexa 488 at $5^{\prime}$ end (Invitrogen).

\section{In Situ Hybridization}

Sections were washed in DEPC $\mathrm{H}_{2} \mathrm{O}(0.1 \% \mathrm{v} / \mathrm{v})$ for 15 minutes to inactivate intrinsic RNases. After carbethoxylation with DEPC, $0.01 \mathrm{M}$ citrate buffer, $\mathrm{pH}$ 6.0, was used as a retrieval solution. The pretreated tissue sections were washed in PBS for 5 minutes. For dspp and dmp-1, the hybridization buffer included $18 \%$ formamide, $2 \times$ standard saline citrate, $1 \times$ Denhardt's solution, $10 \%$ dextran sulfate and $500 \mu \mathrm{g} / \mathrm{ml}$ denatured and sheared salmon sperm DNA. For $\beta$-actin the composition of hybridization buffer was similar with the exception that the concentration of formamide was higher (43\%). A $25-\mu$ l gene frame (ABgene; Thermo Fisher Scientific, Leicestershire, UK) was used for hybridization using $100 \mathrm{ng}$ of each oligonucleotide probe in $25 \mu$ l of hybridization buffer and the hybridization was performed in a Hybaid hybridization oven (Thermo Scientific, Billerica, MA) overnight at $37^{\circ} \mathrm{C}$. Thereafter, sections were washed for $15-$ minute periods with $2 \times$ standard saline citrate at $37^{\circ} \mathrm{C}$ $1 \times$ standard saline citrate at $37^{\circ} \mathrm{C}$, and $1 \times$ standard saline citrate at room temperature. Subsequently, sections were air dried and mounted with Prolong gold antifade reagent with 4',6'-diamidino-2-phenylindole (Invitrogen). Several specificity controls were carried out to eliminate the possibility of nonspecific binding.

\section{RNase Digestion}

Two sections from each sample were treated for two hours at $37^{\circ} \mathrm{C}$ with $200 \mu \mathrm{g} / \mathrm{ml}$ DNase-free RNase A (Qiagen, Doncaster, Victoria, Australia) in PBS. Another section was treated with PBS for 2 hours at $37^{\circ} \mathrm{C}$ to act as a negative control for RNase digestion. One of the RNasetreated sections and the control section were hybridized with $\beta$-actin probe as described above. The other RNasetreated section was stained with Acridine orange.

\section{DNase Digestion}

Two sections from each sample were treated with RNasefree DNase (Qiagen, Australia), 10 Kunitz units/slide, for 2 hours at $37^{\circ} \mathrm{C}$. The other DNase-treated section was stained with Acridine orange.

\section{Hybridization with Sense Oligoprobes}

Three sections from each sample were hybridized with dspp, dmp-1, and $\beta$-actin mRNA sense probes following the same protocol.

\section{Analysis of Calcified Matrix-Related Gene Expression Using Quantitative RT-PCR}

To quantify the impact of carious insult on the expression profile of genes of interest, microdissection of the odontoblast layer adjacent to carious dentin (A-site) and noncarious sites remote from caries ( $R$-site) was performed. 
The $R$-site was microdissected from a nonaffected region of the pulp with a safe margin equivalent to the width of the carious site. Odontoblasts from healthy samples were also microdissected from the occlusal site ( $H$-site) equivalent to $A$-site. Preliminary study did not show any significant differences in $d s p p, d m p-1$, and tgf- $\beta 1$ expression (also reflected at the protein level) between the occlusal and lateral sites in healthy teeth equivalent to $A$ - and $R$-site of carious teeth, respectively. Six consecutive $5-\mu \mathrm{m}$ sections were used for microdissection. Regions of interest were dissected from the tissue using a PALMs Robot-Microbeam system (Zeiss P.A.L.M. LCM microscope) and collected manually under a stereomicroscope (Leica Microsystems).

RNA was extracted from microdissected sections using RNeasy FFPE kit (Qiagen), according to the manufacturer's protocol. Four sections of $5-\mu \mathrm{m}$ thickness were used per preparation and yields were quantified by A260 $\mathrm{nm}$ measurement (Nanodrop ND-1000; Thermo Fisher Scientific). Quality of RNA in samples was assessed using Agilent RNA 6000 Pico Chip (Agilent Technologies, Palo Alto, CA). Reverse transcription of extracted RNA was carried out on $4 \mu$ l of total RNA using the Sensiscript reverse transcription kit (Qiagen), according to the manufacturer's protocol. Briefly, reactions containing $2 \mu \mathrm{l}$ of Sensiscript Reverse Transcriptase, $2 \mu$ l of $10 \times$ reverse transcriptase buffer, $2 \mu \mathrm{l}$ of 2'-deoxynucleoside 5'triphosphate mix (final concentration of $0.5 \mathrm{mmol} / \mathrm{L}$ each 2'-deoxynucleoside 5'-triphosphate), $2 \mu \mathrm{l}$ of $100 \mu \mathrm{mol} / \mathrm{L}$ Random nonamer (Geneworks, SA, Adelaide, Australia) (final concentration of $10 \mu \mathrm{mol} / \mathrm{L}$ ), $2 \mu$ l of RNase inhibitor (10 units/reaction), $6 \mu \mathrm{l}$ of DEPC-treated water were incubated at $37^{\circ} \mathrm{C}$ for 60 minutes and then stored at $-20^{\circ} \mathrm{C}$ until the time of use.

Singleplex real-time quantitative PCR for the genes of interest was carried out using $4 \mu \mathrm{l}$ of the cDNA in triplicate on a Strategene Mx3005P Real-Time PCR System with the Platinum quantitative PCR Supermix-UDG (Invitrogen). Primers together with TaqMan probes against dspp, dmp-1, tgf- $\beta 1$, ocln (occludin), cdh2 (N-cadherin), gjb2 (connexin-26), gja1 (connexin-43) were designed to span exon-exon junctions to prevent genomic DNA amplification and are listed in Table 2. The only exception was gjb1 (connexin 32) with the amplicon designed on exon 2 to detect both transcriptional variants. Transcription profiles of housekeeping genes encoding $\beta$-actin, glyceraldehyde-3-phosphate dehydrogenase and 18S RNA were assessed in healthy and carious teeth. The gene encoding $\beta$-actin was selected as the most constant endogenous reference control (data not shown). Fluorescence intensities were normalized against a passive fluorophore (ROX) present in the Mastermix and

Table 2. TaqMan Primer and Probe Sets

\begin{tabular}{|c|c|c|c|c|}
\hline Gene & $\begin{array}{c}\text { GenBank } \\
\text { accession no. }\end{array}$ & Oligos & Primers & $\begin{array}{l}\text { Expected } \\
\text { amplicon } \\
\text { size (bp) }\end{array}$ \\
\hline TGF- $\beta 1$ & NM_011577 & $\begin{array}{l}\text { F-primer } \\
\text { R-primer } \\
\text { Probe }\end{array}$ & $\begin{array}{l}\text { 5'-CTACCATAGCCAACTTCTGCCTC-3' } \\
\text { 5'-GCCAGGACCTTGCTGTACT-3' } \\
5^{\prime} \text {-CCCTGCCCCTACATTTGGAGCCTGGACA-3' }\end{array}$ & 75 \\
\hline$D S P P$ & NM_014208 & $\begin{array}{l}\text { F-primer } \\
\text { R-primer } \\
\text { Probe }\end{array}$ & $\begin{array}{l}\text { 5'-GCAGAAGGATAGAGAAAGCAAACG-3' } \\
\text { 5'-GGGACCCTTGATTTCTATTCCCTTATC-3' } \\
5^{\prime} \text {-CCAAAGAATCAGAGACACATGCTGTTGGGAAGAGCC-3' }\end{array}$ & 106 \\
\hline$D M P-1$ & $\begin{array}{l}\text { NM_001079911 } \\
\text { NM_004407 }\end{array}$ & $\begin{array}{l}\text { F-primer } \\
\text { R-primer } \\
\text { Probe }\end{array}$ & $\begin{array}{l}\text { 5'-TGTGAACTACGGAGGGTAGAGG-3' } \\
\text { 5'-ACTGGGAGAGCACAGGATAATCC-3' } \\
\text { 5'-CACACCCAACTATGAAGATCAGCATCCTGCTCATGTTCCT-3' }\end{array}$ & 92 \\
\hline$\beta$-Actin & NM_001101 & $\begin{array}{l}\text { F-primer } \\
\text { R-primer } \\
\text { Probe }\end{array}$ & $\begin{array}{l}5^{\prime}-\text { CCTGACGGCCAGGTCATCAC-3' } \\
5^{\prime}-\text { GACTCCATGCCCAGGAAGGA-3' } \\
5^{\prime}-\text { CCGCTGCCCTGAGGCACTCTTCCAG-3' }\end{array}$ & 86 \\
\hline GAPDH & NM_002046 & $\begin{array}{l}\text { F-perimer } \\
\text { R-primer } \\
\text { Probe }\end{array}$ & $\begin{array}{l}\text { 5'-CATCACCATCTTCCAGGAGCGAGAT-3' } \\
\text { 5'-TGAAGACGCCAGTGGACTCCA-3' } \\
5^{\prime}-\text { TACTCAGCGCCAGCATCGCCCCACTTGA-3' }\end{array}$ & 89 \\
\hline 18S RNA & NR_003286 & $\begin{array}{l}\text { F-primer } \\
\text { R-primer } \\
\text { Probe }\end{array}$ & $\begin{array}{l}5^{\prime}-\text { GCCCGTCGCTACTACCGATT-3' } \\
5^{\prime}-\text { GTCAAGTTCGACCGTCTTCTCA-3' } \\
5^{\prime} \text {-GGGCCGATCCGAGGGCCTCACTAAACCAT-3' }\end{array}$ & 106 \\
\hline Occludin & NM_002538 & $\begin{array}{l}\text { F-primer } \\
\text { R-primer } \\
\text { Probe }\end{array}$ & $\begin{array}{l}\text { 5'-GTCTAGGACGCAGCAGATTGGTTT-3' } \\
\text { 5'-GGCCTGTAAGGAGGTGGACTTT-3' } \\
5^{\prime} \text {-AGCTGACCATTGACAATCAGCCATGTCATCCAGGCC-3' }\end{array}$ & 125 \\
\hline N-Cadherin & NM_001792 & $\begin{array}{l}\text { F-primer } \\
\text { R-primer } \\
\text { Probe }\end{array}$ & $\begin{array}{l}\text { 5'-ACGCCGAGCCCCAGTAT-3' } \\
\text { 5'-AGCCGCTTTAAGGCCCTCATT-3' } \\
5^{\prime}-\text { CCGATCTGCAGCCCCACACCCTGGAGAC } \square 3^{\prime}\end{array}$ & 86 \\
\hline Connexin-26 & NM_004004 & $\begin{array}{l}\text { F-primer } \\
\text { R-primer } \\
\text { Probe }\end{array}$ & $\begin{array}{l}\text { 5'-CCTCCCGACGCAGAGCAAA-3' } \\
5^{\prime} \text {-CAATGCTGGTGGAGTGTTTGTTCACA-3' } \\
5^{\prime} \text {-CGTCTGCAGCGTGCCCCAATCCATCTTCTACTCTGG-3' }\end{array}$ & 96 \\
\hline Connexin-32 & $\begin{array}{l}\text { NM_000166 } \\
\text { NM_001097642 }\end{array}$ & $\begin{array}{l}\text { F-primer } \\
\text { R-primer } \\
\text { Probe }\end{array}$ & $\begin{array}{l}\text { 5'-CCAACACAGTGGACTGCTTCGT-3' } \\
\text { 5'-GTACACCACCTCGGCCACAT-3' } \\
\text { 5'-CCGTCTTCATGCTAGCTGCCTCTGGCATCTGCATCATCC-3' }\end{array}$ & 113 \\
\hline Connexin-43 & NM_000165 & $\begin{array}{l}\text { F-primer } \\
\text { R-primer } \\
\text { Probe }\end{array}$ & $\begin{array}{l}\text { 5'-AAGAGTGGTGCCCAGGCAAC-3' } \\
\text { 5'-CCTCCAGCAGTTGAGTAGGCTTG-3' } \\
\text { 5'-GGGTGACTGGAGCGCCTTAGGCAAACTCCTTGACAAGG-3' }\end{array}$ & 85 \\
\hline
\end{tabular}

F-primer, forward primer; R-primer, reverse primer. 
converted to absolute quantities using standard curves for each gene. Visual inspection of the amplified products on $2 \%$ agarose gel electrophoresis confirmed the presence of a single amplicon. Relative expression of targeted transcripts at each site was expressed as the ratio between the average concentrations of each transcript divided by the average concentration of $\beta$-actin transcripts at the same site based on a relative quantification model. ${ }^{28}$

\section{Immunohistochemistry}

Interodontoblastic cells were characterized based on the expression profile of the glial markers GFAP and GS. ${ }^{20,21}$ Immunohistochemical localization of gap junction and tight junction proteins was used to determine the cellular networks and possible routes of communication of cellular elements.

After equilibration in PBS (5 minutes), antigen retrieval was performed with incubation of $1-\mu \mathrm{m}$ sections in 1 $\mathrm{mmol} / \mathrm{L}$ EDTA, $\mathrm{pH} 8$, at $100^{\circ} \mathrm{C}$ for 30 minutes in a microwave oven. Sections were cooled to room temperature and washed in PBS for 5 minutes before processing for immunohistochemistry. Sections were blocked with 10\% horse or goat serum/PBS for 1 hour and primary antibody was applied overnight in $10 \%$ fetal calf serum/PBS at $4^{\circ} \mathrm{C}$. The primary antibodies included mouse monoclonal antiDSP (dilution 1/200; Santa Cruz Biotechnology, Santa Cruz, CA), mouse monoclonal anti-DMP-1 (dilution 1/200; Santa Cruz Biotechnology), rabbit polyclonal anti-GFAP (dilution 1/500; DakoCytomation, Glostrup, Denmark), rabbit polyclonal anti-GS (dilution 1/500; Sigma-Aldrich), mouse monoclonal anti-vimentin (prediluted; Invitrogen, Zymed Laboratories, South San Francisco, CA), goat polyclonal anti-TGF- $\beta 1$ (dilution 1/200; DakoCytomation), mouse monoclonal anti-connexin 26 (dilution 1/200; Invitrogen, Zymed Laboratories), mouse monoclonal anticonnexin 32 (dilution 1/200; Invitrogen, Zymed Laboratories), mouse monoclonal anti-connexin 43 (dilution 1/200; Invitrogen, Zymed Laboratories) and mouse monoclonal $\mathrm{N}$-cadherin (dilution 1/200; Invitrogen, Zymed Laboratories). Sections were also incubated with isotype control antibodies or antibodies of irrelevant specificity to serve as negative controls. After washing with Tris-buffered saline Tween-20 for 30 minutes, fluorochrome-conjugated secondary antibody in 10\% fetal bovine serum/PBS, was added and incubated at room temperature for 1 hour. The secondary antibodies were goat anti-mouse IgG Alexa 488 (dilution 1/500; Invitrogen, Zymed Laboratories) or goat antirabbit IgG Alexa 488 (dilution 1/200; Invitrogen, Zymed Laboratories). The sections were then washed with Trisbuffered saline ( 35 minutes) and mounted onto glass slides using ProLong Gold antifade reagent with 4',6'-diamidino2-phenylindole (Invitrogen, Molecular Probes, Eugene, OR).

For double ISH and immunohistochemistry, consecutive 1- $\mu \mathrm{m}$ sections were used. After ISH for dspp message and immunohistochemistry for connexins 43,32 , and 26 the overlay image was generated. For quantification of fluorescence signal intensity, 13 random regions of interest in the odontoblastic layer were selected begin- ning from $A$-site toward $R$-site. Ten cells were randomly traced in each ROI using Multi_Cell_Outliner plug-in (ImageJ version 1.410; National Institutes of Health). The mean fluorescent intensity from 10 cells in each ROI was calculated according to the following formula after separation of RGB channels using Measure_RGB plug-in:

$$
\text { Intensity }=\frac{\sum_{\mathrm{i}=1}^{10}\left[(\text { Green value }- \text { Red value })_{i} / A_{i}\right]}{10}
$$

where Red value is representative of background value and the intensity is normalized against the area $\left(A_{i}\right)$.

\section{Transmission Electron Microscopy}

For transmission electron microscopy analysis, carious and noncarious pulp samples were cut into small pieces and fixed in Karnovsky's fixative overnight at room temperature, followed by postfixation in $\mathrm{OsO}_{4}$ for 1 hour. Preparations were dehydrated in graded alcohols and embedded in low viscosity resin (TAAB Laboratories and Microscopy, Berkshire, UK). Semithin sections were stained in Toluidine blue to facilitate the selection of site and orientation for preparation of ultrathin sections. Sections were mounted on Pioloform/formvar coated slot grids, stained in uranyl acetate and lead citrate and examined in a Phillips CM10 electron microscope. Film negatives were scanned at $100 \%$ scale at 4000 pixels/ inch using a Nikon Super Coolscan 8000.

\section{Immunoelectron Microscopic Examination}

The carious and noncarious pulp samples were cut into small pieces and fixed with 4\% PFA/0.1\% glutaraldehyde in $0.1 \mathrm{M}$ PBS for 2 hours at room temperature. The tissues were then washed with $0.1 \mathrm{M}$ PBS, dehydrated in graded ethanol and embedded in LRWhite resin (Polysciences, Berkshire, UK). ${ }^{29}$ Ultrathin sections of embedded materials were cut, mounted on nickel grids and processed for immunohistochemistry. ${ }^{30}$ Briefly, antigen retrieval was performed by immersion of grids bearing sections in $0.1 \mathrm{M}$ sodium citrate buffer, $\mathrm{pH} 6.0$, at $95^{\circ} \mathrm{C}$ for 10 minutes. Sections were left to cool to room temperature for 20 minutes in the citrate buffer, jet-washed (deionized water), immersed in drops of $0.5 \mathrm{M} \mathrm{NH}_{4} \mathrm{Cl}$ in $0.1 \mathrm{M} \mathrm{PBS}, \mathrm{pH} 7.3$, for 20 minutes and then washed for 5 minutes in PBS, $\mathrm{pH} 7.3$, containing $1 \%$ bovine serum albumin and $0.1 \%$ Tween 20 (washing buffer). After blocking with 10\% normal goat serum, sections were incubated at $4^{\circ} \mathrm{C}$ overnight on a drop of a solution of polyclonal anti-GFAP antibody (Dako) diluted 1/20 with PBS containing $1 \%$ ovalbumin. Immuno-Gold labeling was performed using the Leica IGL processor (Leica Microsystems). After washing with PBS, sections were exposed to anti-rabbit IgG antibody conjugated with colloidal gold particles of 10-nm diameter (Biocell International, Medford, MA), diluted with PBS (1/40), for 2 hours at room temperature. Ultrathin sections were stained with uranyl acetate and lead citrate and 

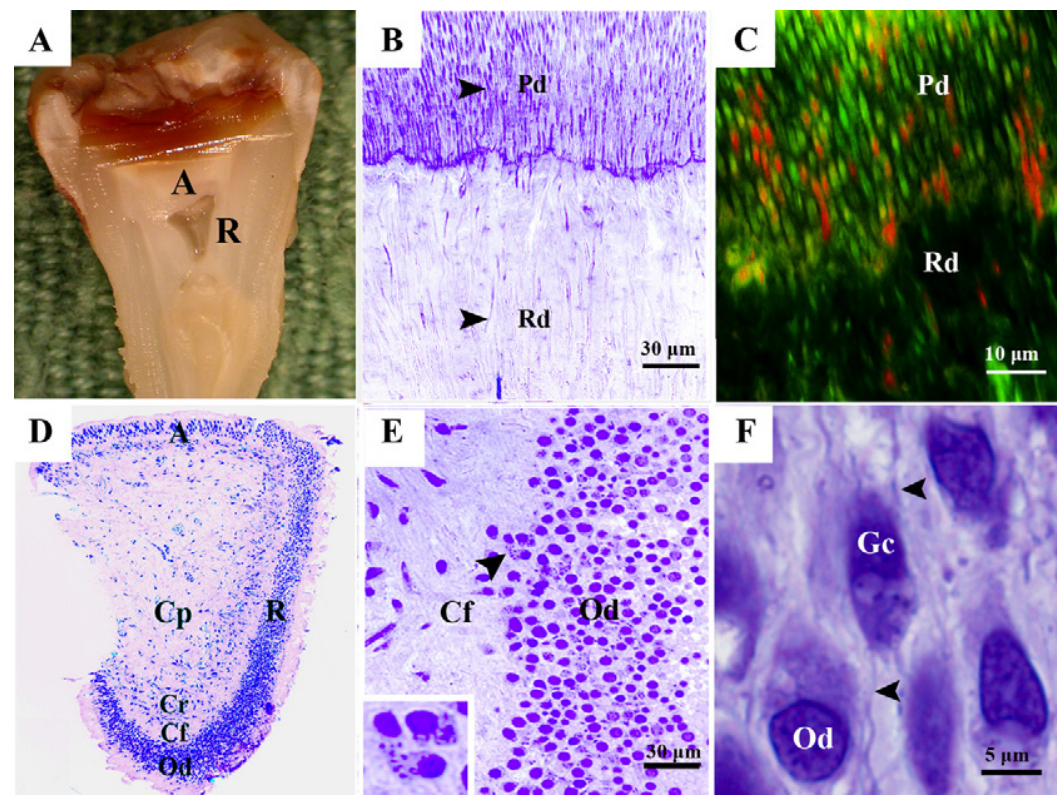

$\mathbf{F}$

$10 \mu \mathrm{m}$

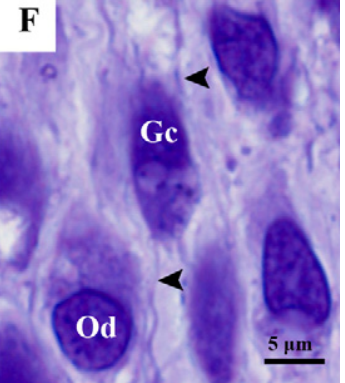

Figure 1. A: Photograph of a split tooth demonstrating the carious lesion and the regions of pulp adjacent to carious lesion ( $A$-site) and remote from that $(R$-site). B: $A$-site showing physiological dentin (top) with a regular tubular structure (arrowhead), and reactionary dentin (bottom) marked with irregularity and scarcity of dentinal tubules (Toluidine blue staining). C: $A$-site showing Acridine orange staining of bacteria (orange-red fluorescence) within the dentinal tubules (green staining), demonstrating accumulation at the interface of physiological and reactionary dentin with few penetrating the reactionary dentin. Specificity for bacteria was confirmed by fluorescence ISH staining using a universal bacterial amplicon on an adjacent section. ${ }^{31}$ In addition this pattern of staining was not observed in healthy teeth. D: Toluidine blue staining of dental pulp (from A) with the odontoblastic layer, cell-free zone, and central pulp. Note the absence of inflammatory infiltrate. E: Toluidine blue staining of odontoblasts in the $A$-site of the carious tooth (A) demonstrating plump nuclei and interodontoblastic cells (arrowhead) with small nuclei and granular cytoplasm (inset). F: Toluidine blue staining of interodontoblastic granular cell extending fine processes (arrowhead). A, $A$-site; R, R-site; Od, odontoblast; Cf, cell-free zone; Cr, cell-rich zone; Cp, central pulp; Pd, physiological dentin; Rd, reactionary dentin; and Gc, interodontoblastic granular cell. examined in a Phillips CM10 electron microscope. Specificity controls were carried out by incubating sections with rabbit IgG negative control antibody.

\section{Statistical Analysis}

SPSS statistical software (version 16; SPSS, Chicago, IL) was used for the statistical analysis of data. Log transformation of data were performed to normalize the distribution of data. The relative expression levels of $d s p p, d m p-1$, and tgf- $\beta 1$ at $A$-site, $R$-site and $H$-site was compared using univariate analysis of variance. Site-specific intensity of TGF- $\beta 1$ staining in carious and healthy teeth was compared using the nonparametric Mann-Whitney U-test. In the present study, $P<0.05$ was considered as statistically significant.

\section{Results}

\section{Histological Evaluation of Pulp-Dentin Complex}

In light microscopic observation, extensive deposition of reactionary dentin by odontoblasts adjacent to the site of carious lesion ( $A$-site) was evident (Figure 1, A and B). Comparison of structure showed distinct differences between physiological and reactionary dentin. Irregular structure was a common feature of reactionary dentin as opposed to the regular tubular structure of the physiological dentin (Figure 1B). The number of tubules in physiological dentin was 20-fold more than reactionary dentin. The degree of anisotropy of the tubular structure of reactionary dentin was 5 times that of physiological dentin (19.17 vs. 4.18). Bacteria were observed traversing the major and accessory dentinal tubules in physiological dentin. Notably, accumulation of bacteria was evident at the border of physiological and reactionary dentin, while few bacteria were detected within the reactionary dentin (Figure 1C). ${ }^{31}$ Of these, none were detected in the inner half of the reaction- ary dentin and in the vicinity of the odontoblasts. The apparent resistance of reactionary dentin to bacterial insult, reflecting its modified structure, was further investigated. Modulation of calcified tissue matrix was suggestive of radical functional adaptations of odontoblasts. Thus, we sought to determine these adaptations.

Three distinct layers were readily observed at the periphery of the pulp; an intact odontoblastic/subodontoblastic layer, cell-free zone, and a cell-rich zone (Figure $1, D$ and $E$ ). Although there was no evidence of inflammatory infiltrate at this stage of lesion development (Figure 1, D and E) several anatomical features of soft tissue changed at the site of bacterial insult. Odontoblasts adjacent to the carious site displayed irregular nonparallel arrangement. Two different cell types were observed within the odontoblastic layer, odontoblasts with bright non-granular cytoplasm and large nuclei and cells with granular cytoplasm and ramified structure located within the odontoblastic layer (granular cells) (Figure 1E, inset). In the carious site, interodontoblastic granular cells were more dispersed and had migrated toward the dentin extending fine processes to contact adjacent cells (Figure 1F). The disruption of planar polarity of odontoblasts and altered calcified matrix formation by these cells was investigated by molecular techniques.

\section{Profiling of the Genes Involved in Formation of Dentin}

DSP (a protein product of dspp) and DMP-1 were expressed in odontoblasts of healthy teeth (Figure 2, A and $B$ ). In carious teeth, while DSP staining was observed in odontoblasts both in A-site and R-site (Figure $2 \mathrm{C}$ ), trace staining for DMP-1 was found only in the $R$-site (Figure 2D).

In ISH assessment of the carious pulp samples, no signal was present for DMP-1 mRNA in either carious or noncarious sites. However, strong expression of DMP-1 

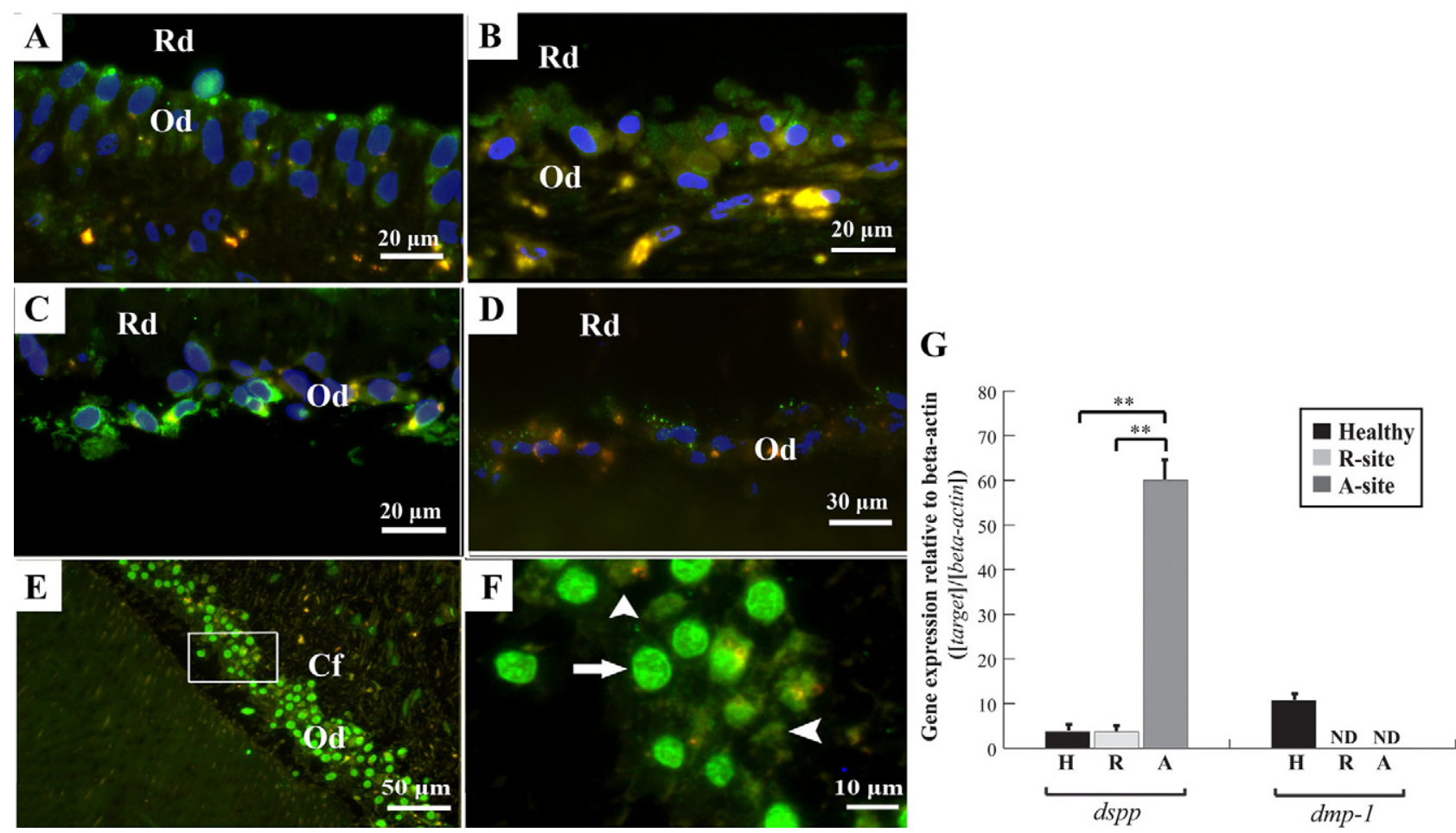

Figure 2. A: Immunohistochemical localization of DSP (A) and DMP-1 (B) in odontoblasts of a healthy tooth. (4', $6^{\prime}$-diamidino-2-phenylindole, blue fluorescence counterstaining). DSP (C) and DMP-1 (D) immunostaining in the $A$-site of a carious tooth. E: FISH identification of $d s p p$ expression in odontoblasts (green fluorescence) also demonstrating nonreactive interodontoblastic cells. Specificity of staining for mRNAs was confirmed by controls (see Materials and Methods). F: Expansion of inset in $\mathbf{E}$ indicating odontoblasts (arrow) and interodontoblastic cells (arrowhead). G: The relative expression of $d s p p$ and $d m p-1$ in healthy teeth and $A$ - and $R$-sites of carious teeth. Showing pooled data $(n=4)$. Error bar represents SEM; ${ }^{* *} P<0.0001$. Od, odontoblast; Cf, cell-free zone; and Rd, reactionary dentin.

mRNA, limited to the odontoblastic layer, was observed in noncarious teeth (data not shown). ISH staining of mRNA from dspp demonstrated strong expression in odontoblasts at the A-site (Figure 2E). A weaker signal was present in odontoblasts in the $R$-site of carious teeth and in healthy teeth. Uniform expression of mRNA from dspp was observed in odontoblasts of healthy teeth, whereas interodontoblastic granular cells did not express dspp mRNA (Figure 2, E and F). Site-specific difference in expression of $d s p p$ and $d m p-1$ was verified by microdissection and quantitative RT-PCR.

Transcriptional activities of $d s p p$ and $d m p-1$ in microdissected regions were evaluated using real-time RTPCR. For accurate comparison of dspp and dmp-1 expression levels between $A$-site, $R$-site and healthy controls, the housekeeping gene $\beta$-actin was used as an internal calibrator gene to control for varying levels of mRNA in each sample. Expression of dspp in the odontoblasts of $A$-sites was 16 -fold greater than for $R$-sites and healthy teeth $(P<0.0001)$ (Figure $2 \mathrm{G})$. Eta for this difference was 0.52 , reflecting a large effect size. However, the expression level of $d s p p$ was not significantly different between odontoblasts in $R$-sites and healthy teeth $(P=$ 0.577). Compatible with ISH findings, expression of dmp-1 was completely suppressed in all pulpal regions of carious teeth, in contrast to uniform expression of this gene in healthy teeth (Figure 2G). Differential expression patterns for $d s p p$ and $d m p-1$ suggested modulation of regulatory mediators. TGF- $\beta 1$ is the best described me- diator of odontoblast function. ${ }^{19}$ Accordingly, the expression and distribution of this mediator was analyzed.

\section{Microanatomical Distribution of TGF- $\beta 1$}

Histologically, TGF- $\beta 1$ was expressed in odontoblasts of carious and healthy teeth. In healthy teeth, expression of TGF- $\beta 1$ was observed in odontoblasts as well as central pulp stromal cells and endothelial cells of blood capillaries. However, expression of TGF- $\beta 1$ protein was stronger in the odontoblastic layer compared to the central pulp (Figure 3A).

In carious teeth, TGF- $\beta 1$ protein showed a gradient mode of expression; weak in the odontoblasts of the $A$-site and increasing in intensity toward the $R$-site (Figure $3, \mathrm{~A}-\mathrm{C})$. This gradient mode of TGF- $\beta 1$ expression was not observed in healthy teeth. Comparison of the average staining intensity between carious and healthy teeth demonstrated significant difference in the $A$-site, which gradually disappeared toward the R-site (Figure $3, \mathrm{~B}$ and $\mathrm{C}$ ).

At the transcriptional level, expression of $\operatorname{tg} f-\beta 1$ in both the $A$ and $R$-sites of carious teeth was 12 - and sixfold less, respectively, than that of healthy control sites $(P<$ 0.0001 ) (Figure 3D). Eta for this difference was 0.55, a large effect size. The expression of message for this growth factor at the $A$-site was $14.2 \%$ less than for $R$ sites. However, this difference did not reach statistical significance $(P=0.2)$. 

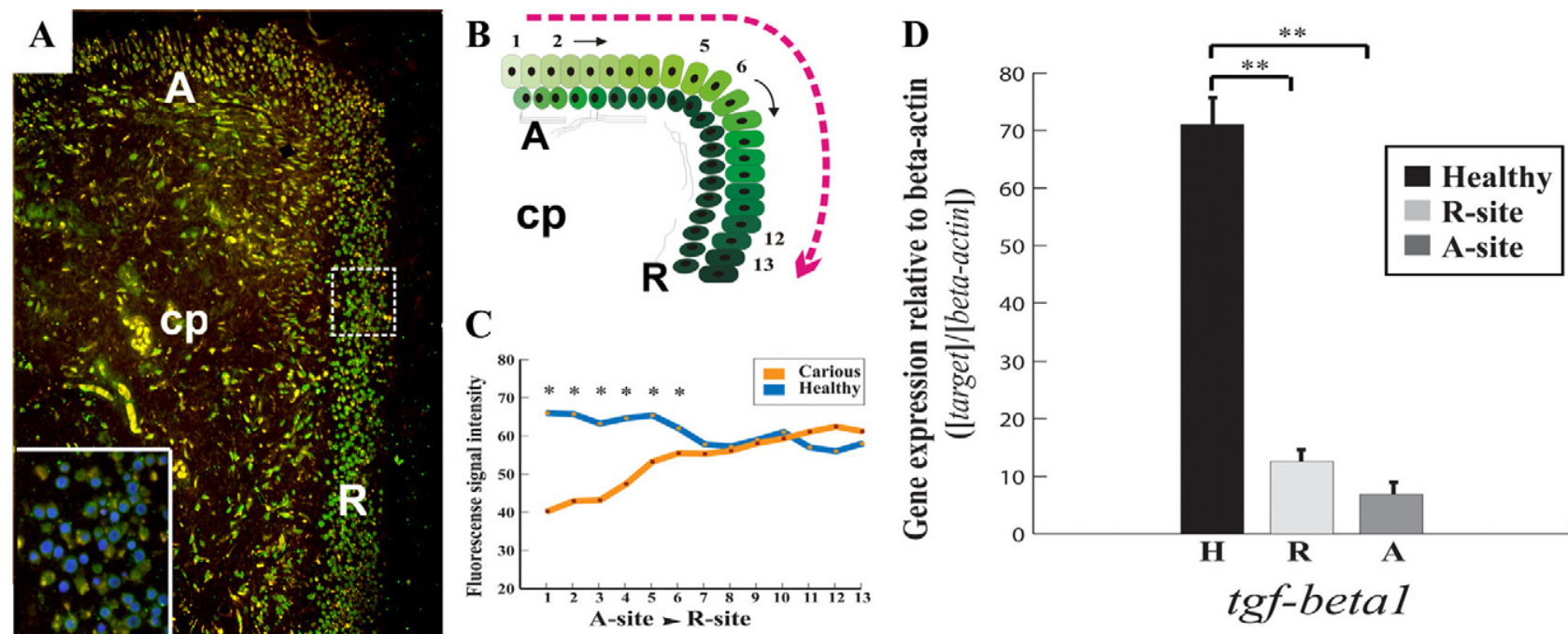

Figure 3. A: Immunohistochemical localization of TGF- $\beta 1$ in the pulp of a carious tooth. TGF- $\beta 1$ is expressed mainly by odontoblasts in a gradient mode decreasing from the $R$-site to the $A$-site. Inset shows double staining of dotted region for TGF- $\beta 1$ and nuclear $4^{\prime}, 6^{\prime}$-diamidino-2-phenylindole (blue fluorescence). B: Schematic representation of a gradient mode of expression of TGF- $\beta 1$ in ROI. C: Statistical analysis of TGF- $\beta 1$ comparing immunolabeling intensity of healthy versus carious teeth from $A$-sites to $R$-sites $(n=4) .{ }^{*} P<0.05$. D: The relative expression of $\operatorname{tg} f-\beta 1$ in healthy teeth and $A$ - and $R$-sites of carious teeth showing pooled data $(n=4)$. Error bar represents SEM; ${ }^{* *} P<0.0001$. A, $A$-site; R, $R$-site; and cp, central pulp.

\section{Characterization of Interodontoblastic Cells}

Expression of vimentin was observed throughout the odontoblastic layer in healthy teeth and carious teeth (Figure 4A). Weak expression of GFAP was observed in granular $\mathrm{DSP}^{-}$cells in healthy teeth with more intense reaction detected in carious teeth (Figure 4B). Expression of GFAP was (Figure 4C) was colocalized with GS (Figure 4D) in granular $\mathrm{DSP}^{-}$cells in healthy and carious teeth. In carious teeth, interodontoblastic DSP ${ }^{-}$granular cells showed expression of GFAP in a gradient mode with stronger signal in A-sites. GFAP and vimentin were not closely colocalized.
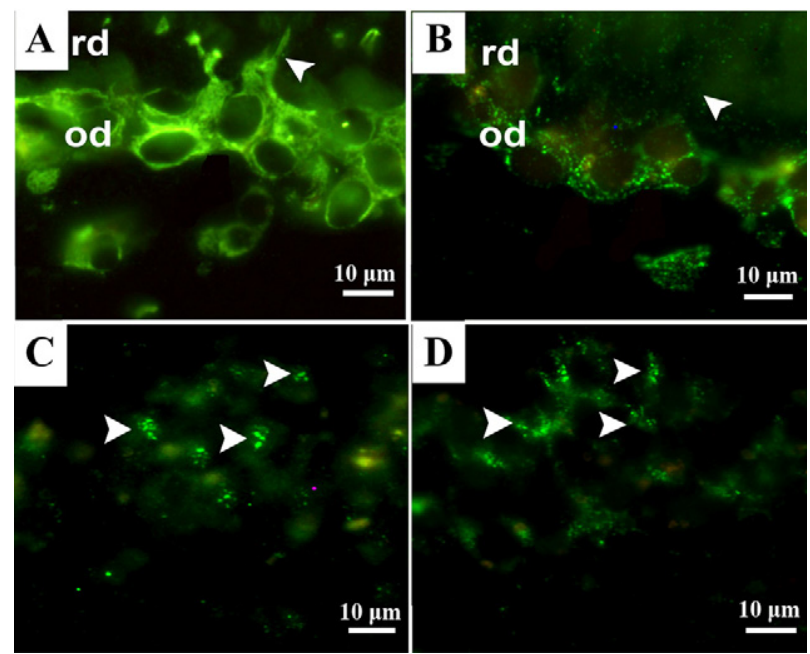

D

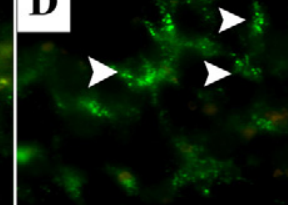

$0 \mu \mathrm{m}$

$10 \mu \mathrm{m}$

Figure 4. A: Expression of vimentin in odontoblasts and interodontoblastic cells in the $A$-site of a carious tooth. Note extension of vimentin filaments into the odontoblastic process within dentin (arrowhead). B: GFAP staining of interodontoblastic cells, extending between the odontoblasts in the $A$-site of a carious tooth. Note the lack of staining in odontoblast process (arrowhead). C: Coincidence of staining (arrowheads) for GFAP (C) and glutamine synthetase (D) in a healthy tooth. od, odontoblast; and rd, reactionary dentin.

\section{Histological and Quantitative Study of Junctional Complexes}

Disturbed planar polarity and population of the odontoblastic layer by granular cells was indicative of alteration of intercellular attachment complexes. Further investigation of junctional complexes revealed major differences in expression of these proteins in $A$ and $R$-sites. Occludin was detected between odontoblasts in healthy teeth and in $R$-sites of carious teeth (Figure 5A). However, in A-sites of carious teeth, occludin was down-regulated suggesting lack of functional tight junctions at these sites (Figure 5B). $\mathrm{N}$-cadherin was expressed in odontoblasts of carious teeth only (Figure 5C). In healthy teeth, moderate staining of connexin 43 was observed (Figure 5D). There was no detectable expression of connexin-32 (Figure 5E) or connexin-26 (Figure 5F) in the odontoblastic layer of healthy teeth. Connexins 26, 32, and 43 exhibited different patterns of expression in the $A$ and $R$-sites of carious teeth (Figure 5, G-I). In carious teeth, connexin 43 was abundantly expressed and connexins 32 and 26 to a lesser extent (Figure 5, G-I). In carious teeth, connexin 43 expression was observed both in granular $\left(\mathrm{GFAP}^{+} / \mathrm{GS}^{+}\right.$ that did not express dspp) cells and odontoblasts (expressing dspp) and was associated with the formation of a network of granular cells (Figure 5, J-L). These findings are summarized in Table 3.

Message for ocln (occludin) in the odontoblasts of healthy teeth was threefold greater than for $R$-sites $(P<$ 0.001 ) (Figure 6). Message for ocln was not detected in the A-site. Message for cdh2 ( $\mathrm{N}$-cadherin) was not detected in odontoblasts of healthy teeth. Expression of cdh2 in the A-site was 1.5-fold greater than for $R$-site $(P<$ 0.01). Expression of gjb2 (connexin-26) and gjb1 (connexin-32) was not detected in odontoblasts of healthy teeth. Although there was no significant difference in expression of gjb1 between odontoblasts in A-site and 

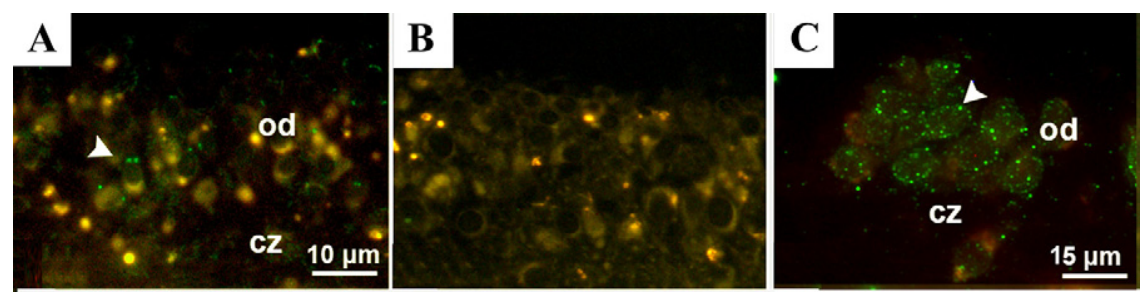

Figure 5. A: The expression of occludin (arrowhead) in the $R$-site. B: Lack of expression of occludin in A-site. C: Peripheral expression of $\mathrm{N}$-cadherin in odontoblasts in the $R$-site of a
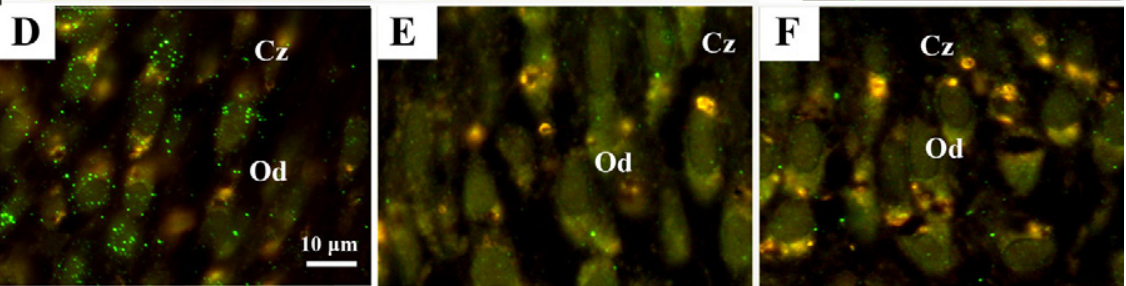

carious tooth (arrowhead). D: Expression of connexin-43 in the odontoblastic layer of a healthy tooth. Lack of expression of connexin-32 (E) and $-26(\mathbf{F})$ in the odontoblastic layer of a healthy tooth. Expression of connexin-43 (G), $-32(\mathbf{H})$, and $-26(\mathbf{I})$ in the odontoblastic layer of the $A$-site of a carious tooth. $\mathbf{J}$ : After ISH identification of $d s p p$ expression in odontoblasts and nonexpressing interodontoblastic cells in the $A$ site of a carious tooth, a region was chosen at random and the outlines of these two cell types overlaid with connexin- 43 (black dots), -32 (yellow dots), and -26 (red dots) from sequential $1-\mu \mathrm{m}$ sections stained for these markers $(\mathbf{K})$ Note the presence of connexin-43 in a network of interodontoblastic cells that do not express $d s p p$ (black arrowheads), odontoblastic-odontoblastic connections (blue arrow) and odontoblastic-interodontoblastic communications (black arrow). L: Schematic drawing representing connexin-43 (black dots), -32 (yellow dots), and -26 (pink dots) expression in $\mathbf{K}$. Note the networks of $\mathrm{GFAP}^{+}$(pink) cells (black arrowheads). Od, odontoblast; and $\mathrm{Cz}$, cell-free zone.
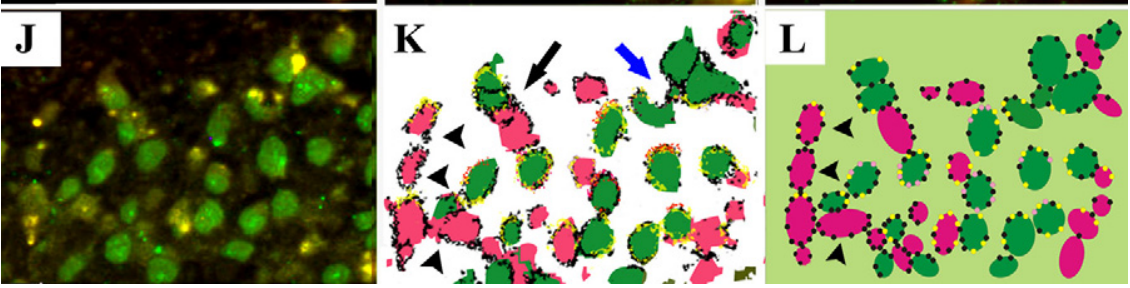

$R$-site $(P=0.448)$, gjb-2 was not detected in the $A$-site of carious teeth. Expression of gja1 in odontoblasts of the A-site was 2.3- and 11.6-fold greater than for odontoblasts at $R$-site and $H$-site, respectively (Figure 6).

\section{Ultrastructural and Immunoelectron Microscopic Analysis}

Semithin sections stained with Toluidine blue indicated structural changes in odontoblastic and interodontoblastic cells in carious teeth. The odontoblasts in the A-site were ensheathed by slender processes of interodontoblastic cells rich in intermediate filaments (Figure 7, A-C). These processes were in close association with odontoblasts through specialized junctions (Figure 7B). Immu- noreactivity for GFAP was present in granular cell processes surrounding odontoblasts in both carious and noncarious teeth (Figure 7D). However, the labeling density of the processes was higher in carious teeth.

\section{Discussion}

Despite the protracted and variable course of caries progression patterns of reactivity observed in this study were consistent and uniform, indicating a strongly imprinted program of adaptation. Using a high-resolution, quantitative approach, it was possible to dissect the characteristic defensive response of this calcified tissue to microbial invasion. The primary indicator was the dep-

Table 3. Summary of Expression of Junctional Complex Proteins in Healthy and Carious Teeth ( $\mathrm{n}=4$ )

\begin{tabular}{|c|c|c|c|c|}
\hline & Location & Healthy & A-site & $R$-site \\
\hline \multirow[t]{2}{*}{ Occludin } & Odontoblast & + & - & + \\
\hline & Interodontoblastic cell & - & - & - \\
\hline \multirow[t]{2}{*}{$\mathrm{N}$-cadherin } & Odontoblast & - & + & ++ \\
\hline & Interodontoblastic cell & - & + & ++ \\
\hline \multirow[t]{2}{*}{ Connexin-43 } & Odontoblast & + & ++ & +++ \\
\hline & Interodontoblastic cell & + & ++ & +++ \\
\hline \multirow[t]{2}{*}{ Connexin-32 } & Odontoblast & - & ++ & ++ \\
\hline & Interodontoblastic cell & - & + & + \\
\hline \multirow{2}{*}{ Connexin-26 } & Odontoblast & - & + & + \\
\hline & Interodontoblastic cell & - & + & + \\
\hline
\end{tabular}

-, no staining; + , trace staining; ++ , moderate staining; and +++ , intense staining. 


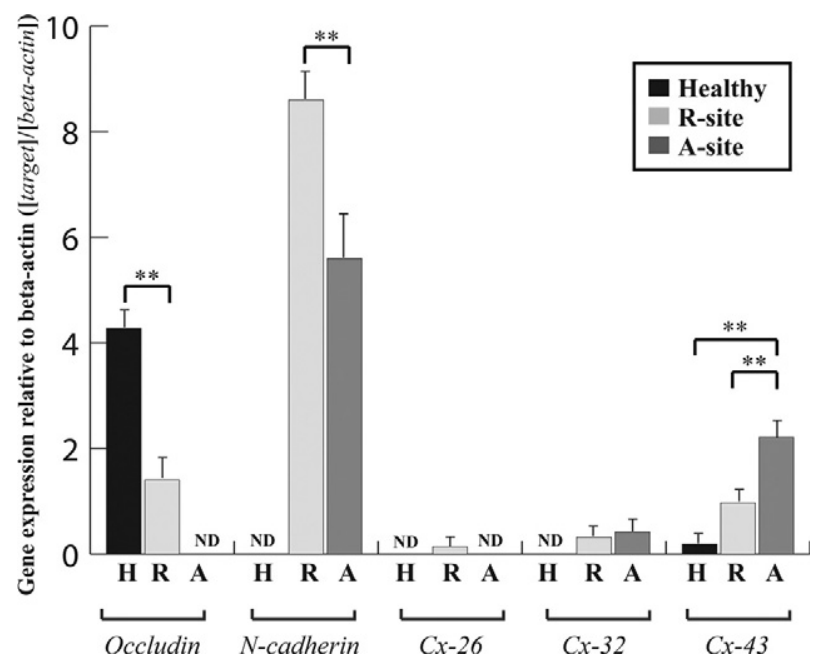

Figure 6. The relative expression of occludin (ocln), N-cadherin (cdh2), connexin-26 (gjb2), connexin-32 (gjb1), and connexin-43 (gja1) in healthy teeth and in $A$ - and $R$-sites of carious teeth showing pooled data $(n=4)$. Error bar represents SEM; ${ }^{* * * *} P<0.01$.

osition of organic matrix and its subsequent mineralization to an anisotropic structure that effectively limited progression of bacteria toward the pulp. Inherent in this response was a gradient of deposition of reactionary dentin. Granular cells of the odontoblastic layer, which expressed GFAP and GS, demonstrated up-regulation of connexin 43 in carious teeth. Study findings are summarized in Figure $8 .{ }^{32}$

Bacterial invasion of dentin is accompanied by the disintegration of dentin matrix and release of bacterial products which stimulate odontoblasts mainly through
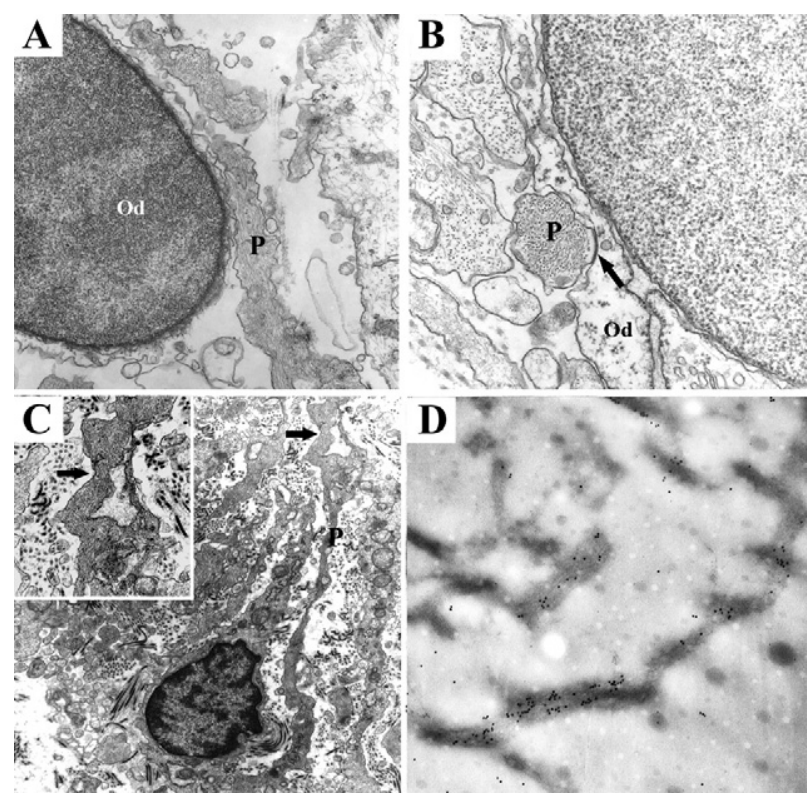

Figure 7. A: Electron micrograph of the $A$-site of a carious tooth, demonstrating intimate association of an interodontoblastic process with an odontoblast. B: Specialized junction (arrow) between an interodontoblastic process rich in intermediate filaments and an odontoblast. C: Interodontoblastic cell with several slender processes rich in intermediate filaments. Inset refers to higher magnification of region marked by arrow. D: Immunogold labeling of GFAP in interodontoblastic cell processes equivalent to those in Figure $7 \mathrm{C}$. Od, odontoblast; and P, interodontoblastic cell process. interaction with pattern recognition receptors, for instance Toll-like receptor-2. ${ }^{33}$ However, the cascade of events following stimulation of odontoblasts had not been described previously. The relatively atubular and disorganized nature of reactionary dentin appeared to limit bacterial invasion. Furthermore, dentinal tubules in reactionary dentin demonstrate projections of mineralized tissue protruding into the lumen. ${ }^{34}$ These findings indicate the importance of occluding dentinal tubules to impede bacterial invasion. The mechanism underlying successful adaptation by odontoblasts to the challenge of encroaching bacteria via modulation of dentin structure implicates radical modification of dentin organic matrix.

Although dspp expression is substantially up-regulated, $d m p-1$ expression is profoundly down-regulated in odontoblasts adjacent to the site of carious insult. This is supported by the findings of McLachlan et $\mathrm{al}^{35}$ who demonstrated increased immunostaining for DSP and DPP (protein products of $d s p p$ ) in carious teeth. An important aspect of successful functional adaptation of odontoblasts to encroaching bacteria, enhanced deposition of dentin barrier, necessitates increased uptake of calcium ions into dentin extracellular matrix through up-regulation of $d s p p$. Overexpression of $d s p p$ promotes mineralization in adipose-derived stromal cells. ${ }^{36}$ Moreover, overexpression of DSP results in an increased rate of enamel mineralization. ${ }^{37}$ In dentinogenesis imperfecta type II mutation of dspp results in decreased mineralization of tooth structure evident as attrition of teeth. ${ }^{38} \mathrm{DMP}-1$ can undergo oligomerization in solution and temporarily stabilize newly formed calcium phosphate nanoparticle precursors by sequestration to prevent further aggregation and precipitation. ${ }^{39}$ This function is important in regulation of microanatomical features of physiological dentin such as maintaining patency of dentinal tubules. Following bacterial insult, down-regulation of DMP-1 could lead to partial or complete obstruction of tubular structure of reactionary dentin and enhanced deposition of apatite, to limit dissemination of bacteria. The relatively disorganized nature of reactionary dentin could be explained by DSP/DPP-mediated acceleration of mineralization and down-regulation of DMP-1 with resultant alteration of anatomical features in reactionary dentin.

Expression of $d s p p$ and $d m p-1$ has been reported in a variety of tissues including but not limited to, bone. ${ }^{32,40,41}$ Products of $d s p p$ regulate both initial mineralization and remodelling phases in bone. ${ }^{42}$ DMP-1 plays an important role in skeletal mineralization through regulation of osteocyte maturation and phosphate homeostasis. ${ }^{43}$ It has been demonstrated in dmp1-null mice that osteocytes exhibit randomly oriented lacunae with marked abnormalities in the distribution and organization of the osteocyte-lacuno-canalicular system. ${ }^{43}$ This anisotropic bone formation associated with down-regulation of $d m p-1$ is equivalent to anisotropic reactionary dentinogenesis accompanying suppression of $d m p-1$ as observed in the present study.

TGF- $\beta 1$ has been implicated as a major regulator of reactionary dentinogenesis. ${ }^{19}$ Our findings demonstrated significant down-regulation of tgf- $\beta 1$ expression (12-fold) at the $A$-site of carious teeth. Down-regulation was also 

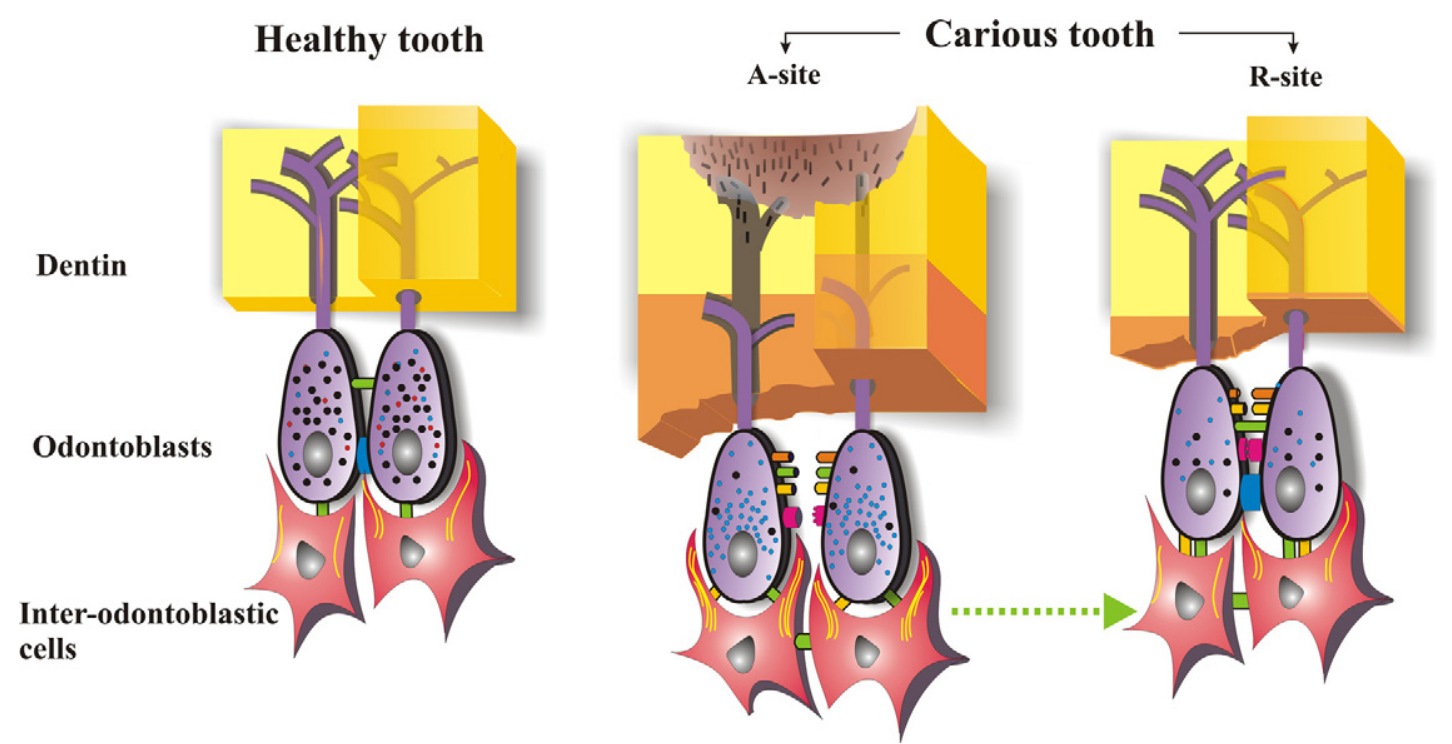

Figure 8. Schematic representation showing response of pulpal cells to invading bacteria. Healthy tooth: processes of the odontoblasts occupy dentinal tubules. Odontoblasts express both $d m p-1$ (red granules) and $d s p p$ (blue granules). There is also strong expression of tgf- $\beta 1$ in these cells (black granules). Intercellular connections between odontoblasts include occludin (blue) and connexin-43 (green). Odontoblasts also connect to interodontoblastic cells through connexin- 43. No intercellular connexins detected in interodontoblastic granular cells. These cells show moderate reactivity for GFAP (yellow filaments). A-site, carious tooth: zone of invasion by bacteria ${ }^{32}$ and extensive deposition of reactionary dentin (orange). Tubules show retracted odontoblastic processes. Marked upregulation of $d s p p$; no detectable expression of $d m p-1$. No detectable staining for occludin. Reactivity in odontoblasts for N-cadherin (red) and connexins 43 (green), 32 (yellow), and 26 (orange). Evidence for intercellular communication in interodontoblastic granular cells mediated by expression of connexin-43. Prominent $\mathrm{GFAP}^{+}$staining (yellow filaments) in interodontoblastic cells. $R$-site, carious tooth: no invasion by bacteria; reduced deposition of reactionary dentin. Expression of $d s p p$; no detectable expression of $d m p$-1. Preservation of intercellular adhesion. Evidence for intercellular communication in interodontoblastic granular cells mediated by expression of connexin 43 (green).

evident in $R$-sites of carious teeth, indicating pan-inhibition of TGF- $\beta 1$ in pulps of carious teeth. There is evidence that TGF- $\beta 1$ down-regulates dspp expression in odontoblasts. ${ }^{44}$ Therefore, there is potential for the observed down-regulation of TGF- $\beta 1$ to contribute to increased mineralization of dentin extracellular matrix via enhancement of transcriptional activity of $d s p p$. Likewise, it has been reported that transgenic mice expressing a cytoplasmically truncated type II TGF- $\beta$ receptor develop an age-dependent increase in trabecular bone mass. ${ }^{45} \mathrm{~A}$ lateral gradient of expression throughout the odontoblastic layer was observed for TGF- $\beta 1$ and $d s p p$ in carious teeth. This finding reflects a pan-tissue response to encroaching infection. The response was localized to the odontoblastic layer, indicating that a local signal transmission network could be responsible for the gradient of deposited reactionary dentin observed.

The expression of GFAP in Schwann cells and undifferentiated stem cells of the central pulp has been reported previously. ${ }^{46}$ Interodontoblastic granular cells which do not express dspp demonstrate low level GFAP expression in healthy pulp. Low expression of GFAP in physiological conditions ${ }^{47}$ and difficulties inherent in detection of the protein ${ }^{48}$ contribute to false negative results. Up-regulated expression of GFAP in granular cells associated with extension of processes of these cells occurred in the context of carious insult. Chen et $\mathrm{al}^{49}$ demonstrated that GFAP expression is necessary for the extension of processes of glial cells in central nervous system tissue. Also, GFAP expression is essential to maintain integrity of Müller glial cell processes in retina. ${ }^{50}$ Thus, we hypothesize that up-regulation of GFAP in inter- odontoblastic cells functions similarly to maintain integrity of elongated processes. Several connexins were identified in odontoblasts and adjacent interodontoblastic granular cells with distinct patterns of expression in carious versus non-carious teeth. There was marked increase in expression of connexins in interodontoblastic cells in carious teeth with connexins 32 and 26 detected as signatures following bacterial invasion. Connexin 43 is expressed during development of human teeth and is subsequently down-regulated. ${ }^{51}$ Trauma-induced upregulation of connexin 43 has also been reported in a variety of other tissues. ${ }^{52}$ Fried et $\mathrm{a}^{53}$ demonstrated that this gap junction protein was confined to sites of contact between adjacent odontoblasts. In addition, coupling of interodontoblastic cells by odontoblasts through gap junctions has been documented by freeze-fracture studies. ${ }^{13,54}$ There is evidence that expression of $\mathrm{N}$-cadherin is associated with up-regulation of connexin 43 and formation of gap junctions ${ }^{55}$ in agreement with findings of the present study.

Connexin 43 is the most abundant gap junction protein in skeletal tissue. ${ }^{56}$ Lack of this protein causes a generalized osteoblast dysfunction, leading to delayed mineralization and skull abnormalities. ${ }^{57}$ Mutation of connexin 43 presents with craniofacial (ocular, nasal, and dental) and limb dysmorphisms, spastic paraplegia, and neurodegeneration characteristic of oculo-dento-digital dysplasia. ${ }^{58}$ Conversely, transplantation of bone marrow stromal cells over-expressing connexin 43 resulted in an increased volume fraction and spatial uniformity of bone in vivo. ${ }^{59} \mathrm{~N}$-cadherin is likewise involved in osteogenesis through controlling the expression of osteoblast gene 
expression and differentiation. ${ }^{60}$ Hence, marked upregulation of connexin 43 and $\mathrm{N}$-cadherin in odontoblasts of carious teeth may function in a similar mode to enhance dentinogenic potential.

A feature of the odontoblastic layer in A-sites of carious teeth was the separation of odontoblasts evident by disrupted planar polarity associated with down-regulation of occludin. This separation could be protective as blocking of gap junctions in neurons has been shown to reduce the size of infarcts after focal ischemia, ${ }^{61}$ and downregulation of occludin desensitizes odontoblasts to proapoptotic stimuli. ${ }^{62}$

Expression of connexin 43 in a plaque-like pattern suggested functional gap junctions and coupling of odontoblasts, rather than hemi-channel formation. ${ }^{63}$ In carious teeth, separation of odontoblasts evident as down-regulation of occludin, combined with prominent expression of connexin 43 by the interodontoblastic cells, indicated a potential for transmission of signals through the network. An analogous situation is the expression of this protein in brain where initially glial cells couple to neurons through connexins. ${ }^{64}$ Following injurious stimuli, glial cells express connexin 43 homo-hexamers to form functional gap junctions at the site of injury and disseminate gliotransmitters to adjacent glia. ${ }^{65}$ In a similar manner, Müller glial cells underlying retinal photoreceptors respond to injurious stimuli by forming networks that transmit signals to adjacent glial cells in a gradient mode. ${ }^{66,67}$ Therefore, we postulate that signal transmission occurs through networks of interodontoblastic $\mathrm{GFAP}^{+} / \mathrm{GS}^{+}$cells mediated via connexin 43 channels to cause modulation of gene expression profiles in odontoblasts in response to infection. In odontoblasts, strong expression of glutamate receptors implicates glutamate as a potential mediator. ${ }^{68}$

In this study evidence is presented for anatomical and functional properties of interodontoblastic $\mathrm{GFAP}^{+} / \mathrm{GS}^{+}$ cells resembling those of Müller glial cells, ${ }^{66,69}$ olfactory ensheathing cells ${ }^{70}$ and supporting cells in the organ of Corti. ${ }^{71}$ The current consensus is that glia in these craniofacial sites are derived from neural crest cells. ${ }^{72,73} \mathrm{Al}$ though these glial cells support sensory structures in neural tissues there is also evidence for a sensory function of odontoblasts. ${ }^{74}$ We propose the term craniofacial, extracerebral, neural crest derivative, sustentacular assemblage to describe glial networks reflecting common developmental, phenotypic and functional properties in these extracerebral craniofacial tissues.

\section{Acknowledgments}

We thank Dr. John Gibbins for assistance in interpretation of results. Ultrastructural studies were performed in the Electron Microscope Laboratory, Westmead, a joint facility of the Institute of Clinical Pathology and Medical Research and the Westmead Research Hub.

\section{References}

1. Arana-Chavez VE, Massa LF: Odontoblasts: the cells forming and maintaining dentine. Int J Biochem Cell Biol 2004, 36:1367-1373
2. Jiang HW, Zhang W, Ren BP, Zeng JF, Ling JQ: Expression of Toll-like receptor 4 in normal human odontoblasts and dental pulp tissue. J Endod 2006, 32:747-751

3. Farges JC, Keller JF, Carrouel F, Durand SH, Romeas A, Bleicher F, Lebecque S, Staquet MJ: Odontoblasts in the dental pulp immune response. J Exp Zoolog B Mol Dev Evol 2009, 312B:425-436

4. Chhour KL, Nadkarni MA, Byun R, Martin FE, Jacques NA, Hunter N Molecular analysis of microbial diversity in advanced caries. J Clin Microbiol 2005, 43:843-849

5. About I, Laurent-Maquin D, Lendahl U, Mitsiadis TA: Nestin expression in embryonic and adult human teeth under normal and pathological conditions. Am J Pathol 2000, 157:287-295

6. Heymann R, About I, LendahI U, Franquin JC, Obrink B, Mitsiadis TA $\mathrm{E}-$ and $\mathrm{N}$-cadherin distribution in developing and functional human teeth under normal and pathological conditions. Am J Pathol 2002, 160:2123-2133

7. Smith AJ, Cassidy N, Perry H, Begue-Kirn C, Ruch JV, Lesot H: Reactionary dentinogenesis. Int J Dev Biol 1995, 39:273-280

8. Lee YL, Liu J, Clarkson BH, Lin CP, Godovikova V, Ritchie HH: Dentin-pulp complex responses to carious lesions. Caries Res 2006, 40:256-264

9. Durand SH, Flacher V, Romeas A, Carrouel F, Colomb E, Vincent C Magloire $\mathrm{H}$, Couble ML, Bleicher F, Staquet MJ, Lebecque S, Farges JC: Lipoteichoic acid increases TLR and functional chemokine expression while reducing dentin formation in in vitro differentiated human odontoblasts. J Immunol 2006, 176:2880-2887

10. Paakkonen V, Bleicher F, Carrouel F, Vuoristo JT, Salo T, Wappler I, Couble ML, Magloire H, Peters H, Tjaderhane L: General expression profiles of human native odontoblasts and pulp-derived cultured odontoblast-like cells are similar but reveal differential neuropeptide expression levels. Arch Oral Biol 2009, 54:55-62

11. Byers MR, Taylor PE: Effect of sensory denervation on the response of rat molar pulp to exposure injury. J Dent Res 1993, 72:613-618

12. Fristad I, Heyeraas KJ, Jonsson R, Kvinnsland IH: Effect of inferior alveolar nerve axotomy on immune cells and nerve fibres in young rat molars. Arch Oral Biol 1995, 40:1053-1062

13. Koling A, Rask-Andersen $\mathrm{H}$ : Membrane junctions in the subodontoblastic region: a freeze-fracture study of the human dental pulp. Acta Odontol Scand 1983, 41:99-109

14. Ohshima H, Maeda T, Takano Y: The distribution and ultrastructure of class II MHC-positive cells in human dental pulp. Cell Tissue Res 1999, 295:151-158

15. Butler WT, Brunn JC, Qin C, McKee MD: Extracellular matrix proteins and the dynamics of dentin formation. Connect Tissue Res 2002, 43:301-307

16. Sreenath $T$, Thyagarajan T, Hall B, Longenecker G, D'Souza R, Hong S, Wright JT, MacDougall M, Sauk J, Kulkarni AB: Dentin sialophosphoprotein knockout mouse teeth display widened predentin zone and develop defective dentin mineralization similar to human dentinogenesis imperfecta type III. J Biol Chem 2003, 278:24874-24880

17. Lu Y, Ye L, Yu S, Zhang S, Xie Y, McKee MD, Li YC, Kong J, Eick JD, Dallas SL, Feng JQ: Rescue of odontogenesis in Dmp1-deficient mice by targeted re-expression of DMP1 reveals roles for DMP1 in early odontogenesis and dentin apposition in vivo. Dev Biol 2007, 303:191-201

18. Ye L, MacDougall M, Zhang S, Xie Y, Zhang J, Li Z, Lu Y, Mishina Y, Feng JQ: Deletion of dentin matrix protein-1 leads to a partial failure of maturation of predentin into dentin, hypomineralization, and expanded cavities of pulp and root canal during postnatal tooth development. J Biol Chem 2004, 279:19141-19148

19. Smith AJ, Tobias RS, Murray PE: Transdentinal stimulation of reactionary dentinogenesis in ferrets by dentine matrix components. $J$ Dent 2001, 29:341-346

20. Reichenbach A, Stolzenburg JU, Eberhardt W, Chao TI, Dettmer D, Hertz L: What do retinal müller (glial) cells do for their neuronal "small siblings"? J Chem Neuroanat 1993, 6:201-213

21. Zhang SC: Defining glial cells during CNS development. Nat Rev Neurosci 2001, 2:840-843

22. Blumberg DD: Creating a ribonuclease-free environment. Methods Enzymol 1987, 152:20-24

23. Massey WL, Romberg DM, Hunter N, Hume WR: The association of carious dentin microflora with tissue changes in human pulpitis. Oral Microbiol Immunol 1993, 8:30-35

24. Hantschick M, Wolf E, Dominok G: The effect of fixation, dehydration 
and polymethacrylate imbedding on the results of immuno- and enzymehistochemical studies on lymphatic tissue and bone marrow. German. Acta Histochem Suppl 1988, 35:165-177

25. Morse A: Formic acid-sodium citrate decalcification and butyl alcohol dehydration of teeth and bones for sectioning in paraffin. J Dent Res 1945, 24:143-153

26. Leu FJ, Chen CF, Sun AM: A new method of tissue processing that causes no shrinkage or distortion. Lab Invest 1993, 69:121-130

27. Brunet-Imbault B, Lemineur G, Chappard C, Harba R, Benhamou CL: A new anisotropy index on trabecular bone radiographic images using the fast Fourier transform. BMC Med Imaging 2005, 5:4-14

28. Pfaffl MW: A new mathematical model for relative quantification in real-time RT-PCR. Nucleic Acids Res 2001, 29:e45

29. Bowling AJ, Vaughn KC: A simple technique to minimize heat damage to specimens during thermal polymerization of $L R$ White in plastic and gelatin capsules. J Microsc 2008, 231:186-189

30. Goode NP, Shires M, Crellin DM, Khan TN, Mooney AF: Post-embedding double-labeling of antigen-retrieved ultrathin sections using a silver enhancement-controlled sequential immunogold (SECSI) technique. J Histochem Cytochem 2004, 52:141-144

31. Nadkarni MA, Simonian MR, Harty DW, Zoellner $H$, Jacques NA, Hunter N: Lactobacilli are prominent in the initial stages of polymicrobial infection of dental pulp. J Clin Microbiol 2010, 48:1732-1740

32. Qin C, Brunn JC, Cadena E, Ridall A, Butler WT: Dentin sialoprotein in bone and dentin sialophosphoprotein gene expressed by osteoblasts. Connect Tissue Res 2003, 44 Suppl 1:179-183

33. Keller JF, Carrouel F, Colomb E, Durand SH, Baudouin C, Msika P, Bleicher F, Vincent C, Staquet MJ, Farges JC: Toll-like receptor 2 activation by lipoteichoic acid induces differential production of proinflammatory cytokines in human odontoblasts, dental pulp fibroblasts and immature dendritic cells. Immunobiology 2009, 215:53-59

34. Klinge RF: A microradiographic and electron microscopic study of tertiary dentin in human deciduous teeth. Acta Odontol Scand 1999 57:87-92

35. McLachlan JL, Smith AJ, Sloan AJ, Cooper PR: Gene expression analysis in cells of the dentine-pulp complex in healthy and carious teeth. Arch Oral Biol 2003, 48:273-283

36. Wu L, Zhu F, Wu Y, Lin Y, Nie X, Jing W, Qiao J, Liu L, Tang W, Zheng $X$, Tian W: Dentin sialophosphoprotein-promoted mineralization and expression of odontogenic genes in adipose-derived stromal cells. Cells Tissues Organs 2008, 187:103-112

37. Paine ML, Luo W, Wang HJ, Bringas P, Jr., Ngan AY, Miklus VG, Zhu $\mathrm{DH}$, MacDougall M, White SN, Snead ML: Dentin sialoprotein and dentin phosphoprotein overexpression during amelogenesis. J Biol Chem 2005, 280:31991-31998

38. Kim JW, Hu JC, Lee JI, Moon SK, Kim YJ, Jang KT, Lee SH, Kim CC, Hahn SH, Simmer JP: Mutational hot spot in the DSPP gene causing dentinogenesis imperfecta type II. Hum Genet 2005, 116:186-191

39. He G, Gajjeraman S, Schultz D, Cookson D, Qin C, Butler WT, Hao J, George A: Spatially and temporally controlled biomineralization is facilitated by interaction between self-assembled dentin matrix protein 1 and calcium phosphate nuclei in solution. Biochemistry 2005 44:16140-16148

40. Godovikova V, Li XR, Saunders TL, Ritchie HH: A rat 8 kb dentin sialoprotein-phosphophoryn (DSP-PP) promoter directs spatial and temporal LacZ activity in mouse tissues. Dev Biol 2006, 289:507-516

41. Feng JQ, Huang $H$, Lu Y, Ye L, Xie Y, Tsutsui TW, Kunieda T, Castranio T, Scott G, Bonewald LB, Mishina Y: The Dentin matrix protein 1 (Dmp1) is specifically expressed in mineralized, but not soft, tissues during development. J Dent Res 2003, 82:776-780

42. Verdelis K, Ling Y, Sreenath T, Haruyama N, MacDougall M, van der Meulen MC, Lukashova L, Spevak L, Kulkarni AB, Boskey AL: DSPP effects on in vivo bone mineralization. Bone 2008, 43:983-990

43. Feng JQ, Ward LM, Liu S, Lu Y, Xie Y, Yuan B, Yu X, Rauch F, Davis SI, Zhang S, Rios H, Drezner MK, Quarles LD, Bonewald LF, White KE: Loss of DMP1 causes rickets and osteomalacia and identifies a role for osteocytes in mineral metabolism. Nat Genet 2006, 38:1310-1315

44. He WX, Niu ZY, Zhao SL, Jin WL, Gao J, Smith AJ: TGF- $\beta$ activated Smad signalling leads to a Smad3-mediated down-regulation of DSPP in an odontoblast cell line. Arch Oral Biol 2004, 49:911-918

45. Filvaroff $E$, Erlebacher A, Ye J, Gitelman SE, Lotz J, Heillman M, Derynck R: Inhibition of TGF- $\beta$ receptor signaling in osteoblasts leads to decreased bone remodeling and increased trabecular bone mass. Development 1999, 126:4267-4279
46. Byers MR, Maeda T, Brown AM, Westenbroek RE: GFAP immunoreactivity and transcription in trigeminal and dental tissues of rats and transgenic GFP/GFAP mice. Microsc Res Tech 2004, 65:295-307

47. Kalman M: GFAP expression withdraws-a trend of glial evolution? Brain Res Bull 2002, 57:509-511

48. McLendon RE, Bigner DD: Immunohistochemistry of the glial fibrillary acidic protein: basic and applied considerations. Brain Pathol 1994, 4:221-228

49. Chen WJ, Liem RK: Reexpression of glial fibrillary acidic protein rescues the ability of astrocytoma cells to form processes in response to neurons. J Cell Biol 1994, 127:813-823

50. Lundkvist A, Reichenbach A, Betsholtz C, Carmeliet P. Wolburg H, Pekny M: Under stress, the absence of intermediate filaments from Muller cells in the retina has structural and functional consequences. J Cell Sci 2004, 117:3481-3488

51. About I, Proust JP, Raffo S, Mitsiadis TA, Franquin JC: In vivo and in vitro expression of connexin 43 in human teeth. Connect Tissue Res 2002, 43:232-237

52. Contreras JE, Sanchez HA, Veliz LP, Bukauskas FF, Bennett MV Saez JC: Role of connexin-based gap junction channels and hemichannels in ischemia-induced cell death in nervous tissue. Brain Res Brain Res Rev 2004, 47:290-303

53. Fried K, Mitsiadis TA, Guerrier A, Haegerstrand A, Meister B: Combinatorial expression patterns of the connexins 26, 32, and 43 during development, homeostasis, and regeneration of rat teeth. Int J Dev Biol 1996, 40:985-995

54. Holland GR: Membrane junctions on cat odontoblasts. Arch Oral Biol 1975, 20:551-552

55. Wei CJ, Francis R, Xu X, Lo CW: Connexin43 associated with an $\mathrm{N}$-cadherin-containing multiprotein complex is required for gap junction formation in NIH3T3 cells. J Biol Chem 2005, 280:19925-19936

56. Civitelli R: Cell-cell communication in the osteoblast/osteocyte lineage. Arch Biochem Biophys 2008, 473:188-192

57. Lecanda F, Warlow PM, Sheikh S, Furlan F, Steinberg TH, Civitelli R: Connexin43 deficiency causes delayed ossification, craniofacial abnormalities, and osteoblast dysfunction. J Cell Biol 2000, 151:931-944

58. Paznekas WA, Boyadjiev SA, Shapiro RE, Daniels O, Wollnik B, Keegan CE, Innis JW. Dinulos MB, Christian C, Hannibal MC, Jabs EW: Connexin 43 (GJA1) mutations cause the pleiotropic phenotype of oculodentodigital dysplasia. Am J Hum Genet 2003, 72:408-418

59. Rosselló RA, Wang Z, Kizana E, Krebsbach PH, Kohn DH: Connexin 43 as a signaling platform for increasing the volume and spatial distribution of regenerated tissue. Proc Natl Acad Sci USA 2009, 106:13219-13224

60. Marie PJ: Role of N-cadherin in bone formation. J Cell Physiol 2002, 190:297-305

61. Rawanduzy A, Hansen A, Hansen TW, Nedergaard M: Effective reduction of infarct volume by gap junction blockade in a rodent model of stroke. J Neurosurg 1997, 87:916-920

62. Osanai M, Murata M, Nishikiori N, Chiba H, Kojima T, Sawada N Epigenetic silencing of occludin promotes tumorigenic and metastatic properties of cancer cells via modulations of unique sets of apoptosis-associated genes. Cancer Res 2006, 66:9125-9133

63. Bukauskas FF, Jordan K, Bukauskiene A, Bennett MV, Lampe PD, Laird DW, Verselis VK: Clustering of connexin 43-enhanced green fluorescent protein gap junction channels and functional coupling in living cells. Proc Natl Acad Sci USA 2000, 97:2556-2561

64. Alvarez-Maubecin V, Garcia-Hernandez F. Williams JT, Van Bockstaele EJ: Functional coupling between neurons and glia. J Neurosci 2000, 20:4091-4098

65. Eugenin EA, Eckardt D, Theis M, Willecke K, Bennett MV, Saez JC: Microglia at brain stab wounds express connexin 43 and in vitro form functional gap junctions after treatment with interferon- $\gamma$ and tumor necrosis factor- $\alpha$. Proc Natl Acad Sci USA 2001, 98:4190-4195

66. Burns MS, Robles M: Muller cell GFAP expression exhibits gradient from focus of photoreceptor light damage. Curr Eye Res 1990, 9:479-486

67. Humphrey MF, Constable IJ, Chu Y, Wiffen S: A quantitative study of the lateral spread of Muller cell responses to retinal lesions in the rabbit. J Comp Neurol 1993, 334:545-558

68. Kim YS, Kim YJ, Paik SK, Cho YS, Kwon TG, Ahn DK, Kim SK, Yoshida A, Bae YC: Expression of metabotropic glutamate receptor mGluR5 in human dental pulp. J Endod 2009, 35:690-694 
69. Ceelen PW, Lockridge A, Newman EA: Electrical coupling between glial cells in the rat retina. Glia 2001, 35:1-13

70. Rela L, Bordey A, Greer CA: Olfactory ensheathing cell membrane properties are shaped by connectivity. Glia 2010, 58:665-678

71. Rio C, Dikkes P, Liberman MC, Corfas G: Glial fibrillary acidic protein expression and promoter activity in the inner ear of developing and adult mice. J Comp Neurol 2002, 442:156-162

72. Giangrande A, Murray MA, Palka J: Development and organization of glial cells in the peripheral nervous system of Drosophila melanogaster. Development 1993, 117:895-904

73. Le Douarin NM, Smith J: Development of the peripheral nervous system from the neural crest. Annu Rev Cell Biol 1988, 4:375404

74. Magloire H, Couble ML, Thivichon-Prince B, Maurin JC, Bleicher F Odontoblast: a mechano-sensory cell. J Exp Zool B Mol Dev Evol 2009, 312B:416-424 